Journal of Healthcare Technology and Medicine Vol. 5 No. 1 April 2019

Universitas Ubudiyah Indonesia

e-ISSN : 2615-109X

\title{
HUBUNGAN FREKUENSI PEMBERIAN MP-ASI DENGAN STATUS GIZI ANAK (6-24 BULAN) DI MUKIM ATEUK KECAMATAN KUTA BARO ACEH BESAR
}

The Relationship Of The Frequency Of Providing Mp-Asi With Children Nutrition Status (6-24 Months) In The Settlement Of Ateuk District, Kuta Baro Aceh Besar

${ }^{1}$ Ismiati, ${ }^{2}$ Yopita Sary

${ }^{1,2}$ Fakultas Ilmu Kesehatan, Universitas Ubudiyah Indonesia, Banda Aceh

Email: ismiati@uui.ac.id

\begin{abstract}
ABSTRAK
Status gizi penting bagi pertumbuhan masa balita. Status gizi dapat dipengaruhi oleh frekuensi pemberian MP-ASI. Kekurangan MP-ASI dapat menimbulkan gangguan pertumbuhan seperti stunting atau anak pendek serta kekurangan zat besi yaitu anemia. Di Provinsi Aceh pemberian MP-ASI pada anak di atas 6 bulan baru mencapai 68,9\%. Data dari Puskesmas Kuta Baro cakupan pemberian MP-ASI baru mencapai $75 \%$ di mana 5,9\% dari total balita menunjukkan pola pertumbuhan. Untuk mengetahui Hubungan Frekuensi Pemberian Makanan Pendamping Air Susu Ibu (MPASI) Dengan Status Gizi Anak Usia 6-24 Bulan di Mukim Ateuk Kecamatan Kuta Baro Aceh Besar. Penelitian ini bersifat analitik dengan pendekatan Cross sectional, dilaksanakan pada tanggal 22 Juli s/d 16 Agustus 2019, populasi dalam penelitian ini adalah seluruh ibu yang mempunyai anak usia 6-24 bulan di Mukim Ateuk Kecamatan Kuta Baro Kabupaten Aceh Besar yang berjumlah 42 orang. Sampel diambil secara total sampling, data yang digunakan data primer dan sekunder dengan menggunakan kuesioner. Uji analisa menggunakan uji chi square. Diperoleh hasil bahwa 42 responden berdasarkan uji stastistik, ada hubungan frekuensi pemberian MP-ASI dengan status gizi anak dengan nilai $\mathrm{P}=0,021(\mathrm{P}<, 0,05)$ ada hubungan frekuensi pemberian MPASI dengan status gizi anak di Mukim Ateuk Kecamatan Kuta Baro Aceh Besar. Disarankan kepada petugas kesehatan untuk dapat meningkatkan lagi penyuluhanpenyuluhan tentang frekuensi pemberian MP-ASI yang baik pada ibu agar ibu mendapat pengetahuan yang lebih baik lagi tentang pemberian MP-ASI demi demi kelangsungan status gizi anak yang baik pula.
\end{abstract}

Kata Kunci : Frekuensi Pemberian MP-ASI, Status Gizi anak 6-24 Bulan 
Journal of Healthcare Technology and Medicine Vol. 5 No. 1 April 2019

Universitas Ubudiyah Indonesia

e-ISSN : 2615-109X

\section{ABSTRACT}

Nutritional status is important for the growth of infancy. Nutritional status can be influenced by the frequency of MP-ASI. Lack of MP-ASI can cause growth disorders such as stunting or short children and iron deficiency, namely anemia. In Aceh Province the provision of MP-ASI for children over 6 months only reached 68.9\%. Data from the Kuta Baro Health Center coverage of MP-ASI has only reached $75 \%$ where $5.9 \%$ of the total toddlers show a pattern of growth. To find out the correlation between the frequency of supplementary feeding of breast milk with the nutritional status of children aged 6-24 months in Mukim Ateuk, Kuta Baro District, Aceh Besar. This research is analytic with cross sectional approach, carried out on 22 July to 16 August 2019, the population in this study were all mothers who have children aged 6-24 months in Mukim Ateuk, District of Kuta Baro, District of Aceh Besar, amounting to 42 people. Samples were taken in total sampling, the data used are primary and secondary data using a questionnaire. Test analysis using the chi square test. The results obtained that 42 respondents based on statistical tests, there is a relationship between the frequency of giving MP-ASI with the nutritional status of children with a value of $P=0.021(P<, 0.05)$ there is a correlation between the frequency of giving MP-ASI with the nutritional status of children in Mukim Ateuk, Kuta Baro District Aceh Besar. It is recommended to health workers to be able to increase counseling again about the frequency of giving good MP-ASI to mothers so that mothers can get better knowledge about giving MP-ASI for the sake of maintaining a good nutritional status of children as well.

Keywords: Frequency of Giving MP-ASI, Nutritional Status of children 6-24 Months

\section{PENDAHULUAN}

Pertumbuhan yang baik bagi Sumber Daya Manusia (SDM) yang akan datang sangatlah penting, hal ini dikarenakan di setiap Negara membutuhkan sumber daya manusia yang berkualitas sebagai pelaksananya. Kualitas anak masa kini merupakan penentu kualitas sumber daya manusia di masa yang akan datang. Oleh karena itu, anak harus dipersiapkan agar dapat tumbuh secara optimal (Kemenkes, 2014).

Periode penting dalam pertumbuhan anak adalah masa balita. Masa di bawah lima tahun (balita) merupakan periode paling kritis dalam menentukan kualitas sumber daya manusia. Pada masa kritis ini dapat terjadi berbagai gangguan. Gangguan pertumbuhan pada anak meliputi gangguan fisik sperti stunted, underweight, gangguan lingkar kepala yang lebih seperti hidrosefalus, megaensefali, dan tumor otak, serta gangguan lingkar kepala kurang dari normal seperti anak menderita retardasi mental, dan malnutrisi kronis (Unicef, 2014).

MPASI ibu sangat penting Masa pertumbuhan bayi berumur lebih dari 6 bulan sampai 12 bulan membutuhkan asupan gizi tidak hanya cukup dengan ASI saja, karena produksi ASI pada saat itu semakin berkurang sedangkan kebutuhan bayi semakin meningkat seiring bertambahnya umur dan berat badan, oleh karena itu bayi harus 
Journal of Healthcare Technology and Medicine Vol. 5 No. 1 April 2019

Universitas Ubudiyah Indonesia

e-ISSN : 2615-109X

mendapatkan makanan pendamping selain ASI. Untuk menutupi kekurangan zat-zat gizi yang terkandung di dalam ASI (Krisnatuti, 2006). 
Journal of Healthcare Technology and Medicine Vol. 5 No. 1 April 2019

Universitas Ubudiyah Indonesia

e-ISSN : 2615-109X

Hasil penelitian Majid (2006), menyatakan ada hubungan antara pemberian MPASI dengan status gizi yang dinilai berdasarkan indeks berat badan menurut usia. Selanjutnya dijelaskan bahwa bayi yang tidak menyusui memiliki resiko berat badan bayi kurang atau kurus sebanyak 8,3 kali lebih besar dibandingkan bayi yang masih menyusui.

\section{METODOLOGI PENELITIAN}

Penelitian ini merupakan penelitian yang bersifat analitik yang dilakukan secara cross sectional, di mana variabel independen dan variabel dependen diteliti dengan bersamaan, yaitu untuk mengetahui hubungan frekuensi pemberian MP- ASI dengan pertumbuhan balita usia 6-24 bulan di Wilayah Kerja Puskesmas Kuta Baro Aceh Besar.

Populasi pada penelitian ini adalah seluruh ibu yang mempunyai anak berusia $\geq$ 6-24 bulan di Mukim Ateuk Kecamatan Kuta Baro Kabupaten Aceh Besar sebanyak 42 orang ibu yang mempunyai balita.

Sampel penelitian ini adalah ibu-ibu yang mempunyai anak berumur $\geq 6-24$ bulan yang berada di Mukim Ateuk Kecamatan Kuta Baro Kabupaten Aceh Besar. Tehnik pengambilan sampel dilakukan secara total sampling yaitu teknik pengambilan sampel secara keseluruhan dari populasi $\square$ Arikunto, 2010 $\square$. Berjumlah 42 orang ibu yang mempunyai anak umur $\geq 6-24$ bulan yang berada di Mukim Wilayah Kerja Puskesmas Kuta Baro .

Instrumen Penelitian ini terdiri atas 2 variabel yaitu variabel bebas (frekuensi pemberian MP-ASI) dan variabel terikat (status gizi), berbentuk kuesioner yang terdiri dari 4 pertanyaan yaitu:

Untuk penilaian variabel bebas yaitu frekuensi pemberian MP-ASI terdapat 3 pertanyaan, dengan indikator yaitu baik dan kurang yang diberikan dalam bentuk kuesioner. Untuk penilaian variabel terikat yaitu status gizi dilakukan dengan cara penimbangan $\mathrm{BB}$ dan pengukuran TB dengan cara sebagai berikut:

a. anak diukur dengan posisi berdiri dengan menggunakan meteran serta ditimbang dengan menggunakan cara menginjak timbangan

b. angka yang ditunjukkan oleh timbangan maupun meteran dicatat dilembaran kuesioner.

c. Kemudian dipilih kolomberat badnuntuk anak laki-laki atau perempuan sesuai jenis kelamin anak

d. Dan dicari angka berat badan yang terdekat dengan berat badan anak.

e. Dari angka berat badan tersebuut dilihat bagian angka standar devisian (SD) anak. 
Journal of Healthcare Technology and Medicine Vol. 5 No. 1 April 2019

Universitas Ubudiyah Indonesia

e-ISSN : 2615-109X

Adapun indikatornya yaitu: kurus, normal dan gemuk. 
Journal of Healthcare Technology and Medicine Vol. 4 No. 2 Oktober 2018

Universitas Ubudiyah Indonesia

e-ISSN : 2615-109X

\section{HASIL DAN PEMBAHASAN}

Hasil penelitian menunjukkan bahwa dari 32 responden yang berada pada kategori frekuensi pemberian MP-ASI baik di mana sebanyak 30 anak $(93.8 \%)$ berada pada status gizi normal. Dari 10 responden yang berada pada kategori frekuensi pemberian MP-ASI kurang baik ada 6 anak $(33,3 \%)$ berada pada status gizi normal.

Hasil uji statistik dengan menggunakan uji chi square didapatkan P-Value $=0,021$ di mana berarti lebih kecil dari pada $\alpha=0,05$. Dengan demikian dapat ditarik kesimpulan bahwa ada hubungan frekuensi pemberian MP-ASI dengan status gizi anak (6-24 Bulan) di Wilayah Kerja Puskesmas Kuta Baro.

Sejalan hasil penelitian yang dilakukan oleh Lestari (2012), menunjukkan bahwa terdapat hubungan yang bermakna antara usia pemberian MP-ASI dengan status gizi (indeks BB/TB) dengan nilai $\mathrm{p}=0,001(\mathrm{p}<0,05)$ di mana 88.9\% anak yang diberikan MP- ASI saat usia $=6$ bulan memiliki status gizi yang lebih baik dibandingkan dengan anak yang telah diberi MPASI dini. Hal ini karena pada saat bayi berusia 6 bulan ke atas system pencernaanya sudah relatif sempurna dan siap menerima makanan padat.

Hasil penelitian Kusumaningsih (2009), menunjukkan bahwa ada hubungan antara frekuensi pemberian makanan pendamping ASI dengan status gizi pada bayi usia 6-12 bulan. Pemberian MP-ASI yang didasarkan pada kebutuhan bayi sesuai usia, jenis, frekuensi, dan jumlah pemberian sangatlah berpengaruh pada status gizi bayi, keadaan kesehatan akan baik jika keseimbangan antara konsumsi dan kebutuhan zat gizi terjamin, maka berat badan akan tumbuh mengikuti usia.

Ariani (2008), menjelaskan bahwa frekuensi pemberian MP-ASI yang cukup dalam hal kualitas dan kuantitas untuk pertumbuhan fisik dan perkembangan kecerdasan anak yang yang bertambah pesat pada periode ini. Bertambah umur bayi bertambah pula kebutuhan gizinya, maka takaran susunya pun harus ditambah, agar bayi mendapatkan energi untuk pertumbuhan dan perkekmbangannya. ASI hanya memenuhi kebutuhan gizi bayi sebanyak $60 \%$ pada bayi usia 612 bulan. Sisanya harus dipenuhi dengan makanan lain yang cukup jumlahnya dan baik gizinya. 
Journal of Healthcare Technology and Medicine Vol. 4 No. 2 Oktober 2018

Universitas Ubudiyah Indonesia

e-ISSN : 2615-109X

Widodo (2010), menyatakan bahwa makanan tambahan adalah makan selain ASI dan susu formula. Seiring dengan pertumbuhan bayi, kebutuhan bayi, kebutuhan akan energi, protein, dan gizi lain nya pun makin bertambah. Suatu saat, kebutuhan tersebut tidak dapat dipenuhi oleh ASI saja sehingga perlu makan lain untuk memenuhi oleh ASI saja sehingga perlu makanan lain untuk memenuhi kekurangannya. Jika makanan tambahan tidak diberikan setelah bayi membutuhkannya, pertumbuhannya akan terhambat. Zat-zat gizi lebih banyak siperlukan dari makanan tambahan terutama dalam memenuhi kebutuhan energi, zat besi, zink, dan vitamin A.

Menurut asumsi peneliti frekuensi pemberian MP-ASI pada usia 6-24 bulan erat hubungannya dengan status gizi anak. Halini dikarenakan pada usia diatas 6 bulan ASI saja tidak dapat mencukupi kebutuhan nutrisi anak oleh karena itu anak memerlukan makanan tambahan lain selain ASI. Selain itu pemberian MP-ASI yang tidak sesuai dengan frekuensi juga dapat berpengaruh terhadap status gizi anak. Di mana pada hasil penelitian terdapat mayoritas status gizi anak berada pada kategori normal dan juga mayoritas frekuensi pemberian MP-ASI baik. Sedangkan anak dengan frekuensi pemberian MP-ASI baik namun status gizi anak cenderung gemuk hal ini dikarenakan pengaruh dari bawaan dari keturunan. Dan anak dengan status gizi kurus hal ini dikarenakan penyakit bawaan yang diderita anak sejak lahir seperti penyakit infeksi.

\section{Kesimpulan}

Hasil penelitian dengan judul "Hubungan Frekuensi Pemberian Makanan Pendamping Air Susu Ibu (MP-ASI) Dengan Status Gizi Anak Usia 6-24 Bulan di Mukim Ateuk Kecmatan Kuta Baro Aceh Besar” dengan 42 responden maka dapat diambil kesimpulan bahwa: Ada hubungan bermakna frekuensi pemberian MP-ASI dengan status gizi anak (6-24 Bulan) di Mukim Ateuk Kecamatan Kuta Baro. Dengan P value = 0,021 ( $<$ 0,05). 
Journal of Healthcare Technology and Medicine Vol. 4 No. 2 Oktober 2018

Universitas Ubudiyah Indonesia

e-ISSN : 2615-109X

\section{Daftar Pustaka}

Ali, A. R., 2010, Penilaian Status Gizi Anak, Dinas Kesehatan Polewali Mandar, Polewali Mandar

Ariani, A, 2008, Peningkatan Berat Badan pada Bayi yangMendapat ASI, PASI, dan Kombinasi ASI-PASI. Majalah Kedokteran Nusantara Volume 40

No. 2 Juni 2009.

Arikunto, S, 2010, Prosedur Penelitian Suatu Pendekatan Praktik, Rineka Cipta, Jakarta

Brown et al., 1992, Evaluation of the impact of weaning food messages on infant feeding practices and child growth in rural Bangladesh, Amj J Clin Nutr, Vol.56 (6), 9941003

Budiarto, E, 2012, Biostastistik Untuk Kedokteran dan Kesehatan Masyarakat, EGC, Jakarta

Imam, M, 2011, Pemanfaatan SPSS Dalam Penelitian Bidang Kesehatan dan Umum, Cita Pustaka Media Perintis, Jakarta

Juwila, O, 2015, Stimulasi, Deteksi dan Intervensi Dini Tumbuh Kembang, [internet] http://www.oktia20. co.id diakses pada tanggal 19 September 2016

Kemenkes RI, 2011, Pelatihan Konseling Makanan Pendamping Air Susu Ibu (MPASI), Kementerian Kesehatan Republik Indonesia, Direktorat Jenderal Bina Gizi Dan Kesehatan Ibu dan Anak, Direktorat Bina Gizi, Jakarta. 